\title{
Resisting the Zionist Grand Narrative and Defying the Palestinian/Arab Metanarrative in Ibrahim Nasrallah's Time of White Horses
}

\author{
Zainab Saeed El-Mansi*
}

May 1948 witnessed the Palestinian Nakba (catastrophe) during which the Zionist $Y i s h u v^{1}$ declared Palestine their homeland. The Palestinian historian and academic Nur Masalha observes in his work, Expulsion of the Palestinians: The Concept of Transfer in Zionist Political Thoughts, 1882-1948, that this resulted in a situation where the Palestinians were systematically and brutally massacred (1993, 175). However, the Zionist hegemonic narrative calls these atrocities, reaching their climax on 15 May 1948, the Israeli Declaration of Independence. Narrating 1948, the Zionist grand narrative and Palestinian/Arab metanarrative ${ }^{2}$ compete over who owns the land, who regains it, and who has future plans for it (Said 1994, xiii); unfortunately, the hegemonic Zionist grand narrative has so far determined answers to these questions. It is not only that the Zionist grand narrative does injustice to the Palestinian Nakba, but ironically - and perhaps also tragically - the elitist male-dominated Palestinian/Arab metanarrative sometimes misrepresents the Nakba. The Palestinian historian Mahmoud 'Issa observes that the Palestinian/Arab metanarrative has always been politically driven and has been dominated by male elite members of the Palestinian society $(2005,180)$, which resulted in marginalising the voices of the fellahin, women, refugees, camp residents and poor uneducated Palestinians. Therefore, since the need for a Palestinian/Arab counter-hegemonic Nakba narrative arises, the aim of this paper is to critically analyse the novel, Time of White Horses (2007) by the Palestinian-Jordanian Ibrahim Nasrallah as an exemplary literary work of Nakba narrative that resists the Zionist grand narrative, defies the Palestinian/Arab metanarrative and represents an authentic Palestinian peasants (fellahin) Nakba narrative.

\section{Theoretical Background}

The equally limiting and limited view of the Palestinian/Arab metanarrative started to change. Masalha observes that recently "historians have been paying

\footnotetext{
* Lecturer at The British University in Egypt (BUE).

Cairo Studies in English (2019-Summer): https://cse.journals.ekb.eg/
} 
increasing attention to the idea of 'social history from below' - or 'from the ground up', thereby giving more space to the voices and perspective of refugees and women $\ldots$ and incorporating extensive refugee oral testimony and interviews" $(2012,219)$. Time of White Horses represents the Nakba from the ground up as it is primarily concerned with the Palestinian fellahin. As a way of representing the voices of the silenced, Nasrallah relied on oral testimonies of several Palestinian witnesses and survivors to write Time of White Horses (Nasrallah 2012, ix). Therefore, analysing the novel would be in light of resistance literature. In fact, the late Palestinian prominent literary figure, critic and revolutionary, Ghassan Kanafani (1936-1972) was the first to call Palestinian literature as resistance literature in his study Literature of Resistance in Occupied Palestine: 1948-1966 (Harlow 1987, 2). Kanafani defines resistance literature as "writing within a specific historical context, a context which may be most immediately situated within the contemporary national liberation struggles and resistance movements against Western imperialist domination" (qtd. in Harlow 1987, 4); this could describe the Palestinian literary work of concern here. Resisting the Zionist grand narrative that denies the existence of the Palestinians, Nasrallah is keen to represent a glorious Palestinian history. Accordingly, Time of White Horses includes many elements of the epic novel. Defining the epic genre, Mikhail Bakhtin states that it is primarily concerned with: a) the "national ... past [that] serves as the subject for the epic; b) the national tradition [that] serves as the source for the epic; c) an absolute epic distance [that] separates the epic world from contemporary reality" $(1981,13)$. Time of White Horses revolves around Palestine in the nineteenth century with the aim of representing chivalrous Palestinian men.

Nasrallah's novel has also certain postmodern features that correspond with what Linda Hutcheon calls 'historiographic metafiction,' a term which "refutes the ... common-sense methods of distinguishing between historical fact or fiction. It refuses the view that only history has a truth claim, both by questioning the ground of that claim in historiography and by asserting that both history and fiction are discourses, human constructs, signifying systems, and both derive their major claim to truth from that identity" (Hutcheon 2000, 93). Time of White Horses intermingles historical figures and events with fictional characters to deconstruct the claims of the Zionist grand narrative and defy the Palestinian/Arab metanarrative. Further, a basic feature of historiographic metafiction is transtextuality, which is defined by the French critic and theorist Gérard Genette as "the textual transcendence of the text" $(1997,1)$. The two types of transtextuality that Nasrallah uses here are paratextuality and 
intertextuality to further deconstruct several Zionist claims, but the most prominent of all is the famous Zionist slogan: "a land without a people for a people without land."3 From this perspective, the authority of the author influences both the meaning and ideology of his text.

\section{Time of White Horses as Part of a Palestinian Resistance Literary Project}

Nasrallah's novel simultaneously resists the Zionist grand narrative and defies the Palestinian/Arab metanarrative. Time of White Horses was shortlisted for the International Prize for Arabic Fiction in $2009^{4}$ ("Ibrahim Nasrallah" 2015). It is part of Nasrallah's project The Palestinian Comedy $y^{5}$ in which he documents, in a fictional wrap, the atrocities that the Palestinians have been subjected to throughout history. Nasrallah was greatly offended by Ben Gurion's declaration: "the old [Palestinians] will die and the young will forget", which he saw equivalent to the Zionist statement: "had the Palestinians been a people then they would have had a literature" (Nasrallah "On Writing the Palestinian Historical Novel" 2012). Accordingly, he embarked upon this literary project to foreground the Palestinian identity and literature. On the other hand, with the continual misrepresentation of the Nakba, the Palestinian/Arab metanarrative has marginalised any national aspiration that the Palestinians ever had; for example, it has marginalised the Palestinian Great Revolt (1936-1939) and ignored its main figure Ezz Al-Deen Al-Qassam (1882-1935) (Swedenburg 1995, 3). Nasrallah defies this in his novel by centralising the Palestinian fedayeen's resistance during the Revolt.

Set in the fictional village al-Hadiya, Time of White Horses is a Palestinian saga that tackles a span of seventy-five years of the Palestinian struggle, starting from the end of the nineteenth century until the Nakba. Choosing a village to be the setting of the whole narrative significantly serves Nasrallah's aim of presenting the Palestinian authentic fellahin narrative because the village was "the most important unit in the fellah's [peasant's] life" (Ruedy 1971, 122). Nasrallah sought to foreground the fellahin resistance because they were the backbone of fighting the British and Zionist occupations (Sayigh 2007, 4). Thus, the novel focuses on Khaled Al-Hajj Mahmoud's resistance against the Turkish Ottoman Rule and the British colonial rule.

\section{Turath and Arab Culture as a Means of Resistance}

Colonial practices seek to destroy the colonised people's culture and heritage. Frantz Fanon explains that colonialism "[b]y a kind of perverted logic ... turns to the past of the oppressed people, and distorts, disfigures and destroys it" $(1970,169)$; Zionism is no different. In order to secure the disappearance of the 
Palestinian people, the Zionist grand narrative has deployed what is known as cultural genocide which is defined by the Jewish Polish lawyer Raphael Lemkin, who himself coined the word "genocide", as: "the destruction of the cultural pattern of a group, such as the language, the traditions, the monuments, archives, libraries, churches. In brief: the shrines of the soul of a nation" (qtd. in Docker 2004). Writing a Palestinian counter-hegemonic narrative, Nasrallah relies, in his novel, on turath (traditional) elements to preserve the Palestinian identity and heritage.

Time of White Horses begins with a culturally significant place in the nineteenth century Palestinian fellahin's houses; the madafa (Guest House). The madafa, in the novel, is the place in which many decisions are taken throughout the course of the narrative. For instance, it is the place in which Shaykh Nasir Al-Ali, "one of the most prominent clan-based judges in the country" (Nasrallah 2012,18 ) saves the marriage of Khaled, the main character in the novel. It is also the place in which the elders meet strangers. For example, the madafa is where the horse Hamama's owners come to claim her back. The cultural significance of the madafa is worth mentioning here. Traditionally speaking, the madafa is a place detached from the house; it "can be described as a multifunctional public space for socialising between men as well as for coordinating all sorts of communal duties, responsibilities and services in the village" (Büssow 2011, 120). It is where the village men learn their ancestors' traditions, ethics and morals that would help them lead a decent life. The seating system in the madafa reflects how the Palestinians respect social order and decorum: it was the norm in pre-1948 Palestine that the person sitting in the centre of the madafa is the village elder and around him sit the rest of the fellahin depending on their social status and role in their community. In some cases, the centre of the madafa was left to a religious scholar or sheikh in a gesture of respect and appreciation as it was the norm in Ottoman Palestine that fellahin would respect the older people and those with high social and religious ranks (Al-Moubaid 1990, 519-21). This deconstructs the Zionist claim that the Palestinians were merely savages, violent, immoral group of Arabs $^{6}$. Thus, giving the madafa this value signifies celebrating the Palestinian past (Slyomovics 1998, 140).

The madafa is also a place in which the Palestinians used to greet their guests by serving them coffee. The task of making coffee was dedicated to a certain person who uses special tools to roast, grind, boil and then serve coffee (AlMoubaid 1990, 522). The coffee maker used his mortar and pestle to grind coffee, while making a beautiful rhythm that was sometimes accompanied by songs (Al-Moubaid 1990, 523). The tradition of coffee making is another 
element of the Palestinian turath that Nasrallah represents in his novel. The character assigned to making coffee, in Nasrallah's narrative, is Hamdan: "Every time he ground coffee for a guest, Hamdan would come up with a special rhythm suited to the occasion" (Nasrallah 2012, 30).

\section{Deconstructing the Zionist Grand Narrative}

As the roots of Zionist colonisation of Palestine go back to the nineteenth century (Masalha 1993, 5), Nasrallah sets his novel in the same historical epoch when Palestine was part of the Turkish Ottoman Empire. The novel dwells upon the harsh tax system that the Turkish Ottomans imposed on the Palestinians and the sudden building of the Greek Orthodox Monastery in Hadiya; two factors that would have cost the fellahin their land. Nasrallah's resistance narrative "provides a more developed historical analysis of the circumstances of economic, political, and cultural domination and repression and through that analysis raises a systematic and concerned challenge to the imposed chronology" (Harlow 1987, 78) of the Zionist grand narrative; thus, deconstructing the famous Zionist slogan and the myth that claims that the Palestinians abused the land whereas the Zionists brought life to it (Ramras-Rauch 1989, 6). A short summary of land tenure in Palestine during the Ottoman era is important here. Most rural land in the Ottoman Empire was

held hereditary on a usufruct basis known as miri. Tenure could in theory be terminated for a number of reasons, including, principally, failure to cultivate or non-payment of taxes. . . The government also owned a considerable amount of land, jiflik, which it rented as landlord on longterm or short-term leases to cultivators directly or through the intermediary of larger private landlords. . . The individual's rights were always expressed as a fraction of the whole. In most villages, each constituent kinship group had become entitled to a fixed proportion of soil of each quality represented in the holding. This system called masha' $a$, was seen by the British and Zionist observers as economically unsound. ... From a social and psychological point of view, however, and as a reflection of the dependence of the individual upon the group for every security during a disorganized period of history, masha'a represents an appropriate adaptation. (Ruedy 1971, 122-23)

The harsh tax system that resulted in land loss was enforced in the following manner. Being financially exhausted after the end of the Crimean War (18531856), the Ottoman Empire issued the Ottoman Land Code shortly afterwards, 
in 1858. The new land code was part of the Tanzimat (Reform) period that sought to reform land tenure and taxation among other things (Essaid 2014, 58). This law was issued for several reasons: first, increasing "the area of cultivated land [and] bringing as much mahlul (land uncultivated for over 3 years), and mewat (dead) State land under cultivation as possible" (Kark 2017, 102), resulting in the second reason which is increasing tax revenue. This law was followed by another law in June 1867 that signalled the beginning of land loss in Palestine: "On 10 June 1867, a law was published permitting foreign citizens to acquire urban and rural land in all areas in the empire, with the exception of the Hijaz ... The purchasers included the churches and missions, the Temple Society (German Templers), private initiators, and Jews" (Kark 2017, 103); that was one of the ways by which the Zionist Yishuv acquired land in Palestine. From a historical perspective, this deconstructs the Zionist claim that the Palestinians willingly sold their land to Zionist "pioneers" during the nineteenth century (Oppenheimer 2012, 383).

In the nineteenth century, the Greek Orthodox Church built a monastery in Nasrallah's village Burayj, the representation of which is found in Time of White Horses (Nasrallah 2012, x). Nasrallah foregrounds the monastery's colonial aims rather than its religious identity. Historically speaking, the Greek Orthodox Church in Palestine enjoyed a privileged position that allowed it to gain control over important holy places, one of which is the Church of the Holy Sepulchre. Colonising a country entails creating interests such as religion-based ones; this happens by means of creating a complex apparatus for attending to such interests such as the church (Said 1994, 100). Therefore, the monastery in the novel is represented as a colonial entity inside Hadiya. The Palestinian laity's role was restricted to being supplicants. Though some of them could have been well educated, such as Father Elias in the novel, they were prohibited from becoming monks in the brotherhood (Robson 2011, 77-8). Though Time of White Horses includes a detailed practice of the Greek Orthodox monastery in the village, the novel, unlike some Zionist literary narratives ${ }^{7}$ does not have any religious motif. Nasrallah eloquently presents Hadiya as a village that encompasses Muslim and Christian Palestinians who suffer from the presence of this foreign entity. Such coexistence is absent in Zionist writings; one of which is Alon Hilu's The House of Rajani (2008). Hilu denies the existence of Palestinian Christians, in Ottoman Palestine, and represents, instead, a land that is inhabited by Muslims and Jews only which renders the struggle over Palestine a religious one. It is this particular claim that Nasrallah seeks to deconstruct here. 
Deconstructing the famous Zionist slogan that denies any presence of the Palestinians during the nineteenth century, Nasrallah presents the nineteenth century Palestinians' struggle with the Greek Orthodox Church's colonial attempts to exploit their land and annihilate the Muslim identity of some Palestinians. Christianity is the religion of the White coloniser; thus, it is the religion of "civilisation." The Christian missionaries' activities have always been indirect ways of colonising non-Furopeans. By spreading the loving and peaceful teachings of Christianity, the colonised is fooled to believe the good intentions of the colonisers. The church in Hadiya is a hegemonic entity (Gramsci 2007, 64) that forces its principles on the small village society. In the context of the novel, the church also functions as a school. Schools are social institutions used sometimes to spread the cultural hegemony of the ruling class, but in this context, it is the hegemony of the foreign entity in the village. The monastery's missionary activities began with appealing to the villagers' need to educate their children, which echoes Fanon's perception of colonialism: "the total result looked for by colonial domination was indeed to convince the natives that colonialism came to lighten their darkness" $(1970,169)$. Hajj Mahmoud, consequently, makes an agreement with Father Georgiou who states that the "Muslim children [would] simply learn to read and write [and the] Christian children [would] ... attend lessons on religion if they chose to" (Nasrallah 2012, 50). Nevertheless, this agreement is breached by the evangelist Antonius who "would slip booklets of Bible stories containing simplified Christian doctrine into the children's pocket" (Nasrallah 2012, 35) and urges the children to memorise them in return for a piece of chocolate. Breaching the agreement signifies that this Father disregards the Palestinian elder and proves the colonial nature of their project.

As it is land that is contested over in the Zionist and Palestinian narratives, Nasrallah dedicates a large part of his novel to discuss the Ottoman harsh tax system, the Greek Orthodox monks' usurpation of the land's produce and their abuse of the collected tax. Similar to the Zionist colonisers, the Greek monks aimed to dominate the land; but unlike them, the monks did not seek to expel the Palestinians from their land. The land is the centre of attention of Father Georgiou and Father Theodorus who are certainly determined to usurp it from its rightful owners. The foreign Christians of the monastery appointed themselves owners of the land and set to make use of its fertility and produce. Father Georgiou, like other members of the Greek Orthodox Church in Palestine, "took vows of chastity and obedience but -- significantly -- not poverty" (Robson 2011, 77). Father Georgiou is sure that the monastery's presence in Hadiya would grant him privileges: "he would be able to collect the tithe, which he could 
dispose of however he pleased, as well as the basket of fruit and vegetables, the jars of milk, and the cheeses that came into the monastery in a never-ending stream from one season to the next" (Nasrallah 2012, 54). Father Georgiou's greed does not stop here; he also makes use of the offerings by the generous villagers to the church. Actually, Father Georgiou could be easily described as a common thief, exactly as Ghada Karmi described the Zionist Yishuv (Al Jazeera English 2013, 16:18-30). The villagers willingly give the monastery the tithe to pay the Ottoman Empire their taxes giving the opportunity to Father Georgiou, and other Greek Fathers as well, to steal their money. Father Theodorus, who is the successor of Father Georgiou, does not hide behind a friendly mask as Father Georgiou did. Father Theodorus invites himself to stroll in the land to be certain of its fertility and produce: "Not a day had passed since his arrival in Hadiya but that [the villagers] had seen him touring the village's fields and orchards" (Nasrallah 2012, 72). Like his predecessor, Father Theodorus is keen to have the tithe of the land claiming that the monastery would pay it to the Ottoman authorities; he asserts, and at the same time threatens, Hajj Mahmud in an undertone that he has to get the full tithe: "Don't forget, Hajj, that what you all give me is something I owe the state, and I wouldn't want to come before the authorities with an incomplete tithe" (Nasrallah 2012, 72).

Though Nasrallah does not mention the Crimean War or the Ottoman Empire's financial crises, he elaborates upon the war's consequences on the Palestinian fellahin as they are his main concern. However, he does not victimise the Palestinians, rather he shows their naivety and blind trust of the coloniser. Hajj Mahmoud, like the other fellahin, unwittingly trusts the Greek Orthodox Church. He tells Father Georgiou "because we trusted you ... we began paying you one-tenth of our crops and even more. So now, we pay you, and you in turn go and pay taxes on our behalf" to the Ottomans (Nasrallah 2012, 36). The system of paying the fees and taxes is probably the Maqtoo' whereby "peasants pay a fixed amount of money on an annual basis, whether or not there is an increase in the land's produce" (Mahafzah and Abd Al-Lateef 2009, 100). This tax was collected by "bidders at annual public auctions, usually to city merchants and moneylenders" (Sayigh 2007, 7), but in Hadiya's case, it is the Fathers of the monastery who would do this job. It was a normal procedure; maybe that is why the peasants did not suspect any colonial motives. Hajj Mahmoud explains to his son "the people at the monastery know more than we do, and they know what to do when they go there. If we went ourselves, we might have to pay a lot more. And, as you can see, we're trying in every way to free ourselves from the Turks' iron grip" (Nasrallah 2012, 36). Hajj Mahmoud accepts the monastery's 
authority over the peasants and consequently the land; he unwittingly tries to drive off a colonial domination by another one. This power is granted to the monastery people in the form of "knowing" more than the villagers; as knowledge "induces effects of power" (Foucault 1980, 52). Hajj Mahmoud's greatest fear is the loss of the land especially that the "the Turks had sold scores of villages at public auction to landowners in Syria and Lebanon. The villages in question had been unable to pay the tithe for a number of years running, and as a result had accumulated large debts to the state" (Nasrallah 2012, 72).

Moved by their determination to resist the Ottoman Empire's unjust system, the Palestinians were indirectly responsible for land loss. Some of the fellahin, driven by an urge to resist tyranny and fear, did not register their land according to custom during Ottoman rule of Palestine. In Hadiya, some actually trusted the deeds of their land to the Greek Orthodox monastery: Hajj Mahmoud clarifies to Khaled " $[\mathrm{t}]$ here are ... people among us who haven't registered their land in their names. However, every one of us knows exactly where his land begins and ends ... This is the way it's been since time immemorial" (Nasrallah 2012, 36). At that time, there were no official documents attesting to a person's legal title to any land; ownership of a certain part of the land was established by tradition (Aumann 1974, 117). Not registering the land officially is one of the ways by which the Palestinian villagers resisted the Turkish tyranny: "the existence of a deed could only mean one thing, namely that [they] would have to pay more taxes" (Nasrallah 2012, 36) especially that these taxes have been unjust. The Palestinian villagers, at that time, did not comprehend the "the concept of 'ownership', so foreign was it to their own concept of 'right"' to the land (Sayigh 2007, 27). Further, the villagers' fear that the Turkish Ottoman army recruiter and the tax collector would make use of registering the land made them refuse the whole concept (Ruedy 1971, 124). Answering the hypothetical question of someone claiming the land, which became reality after a few years, Khaled's grandfather shouts angrily "[c]ould somebody come along and divorce me from my wife?" (Nasrallah 2012, 37), signifying the deep relation between these villagers and their land. This land is elevated to the level of human beings. The Palestinians "feel a 'mystical affinity' with their land as the sources of their human and social systems" (Mir 2013, 124). Accordingly, Nasrallah deconstructs Benny Morris' claim that the Palestinians before 1948 were mere "Arabs" with no distinctive identity and no land to hold to $(2004,42)$. In this sense, the novelist subtly explains the loss of some acres of land and defies the Zionist grand narrative. 


\section{Defying the Palestinian/Arab Mainstream Nakba Narrative}

Time of White Horses does not stop only at deconstructing the Zionist grand narrative, precisely the famous Zionist slogan, it moves forward to defy the Palestinian/Arab metanarrative. In the Arab collective memory, women are traditionally seen as weak and dependent on their male kinship. Many literary works follow the famous analogy that equates "land with women and women with land" (Faulkner 1985, 847); the Palestinian literature is no different. In addition to representing land, women have also come to represent the mother figure in Palestinian literature. ${ }^{8}$ This might be due to the Palestinians' loss of land; i.e. life giver, which renders women symbols of fertility and love. Contrary to the literary works of major Arab writers who deal with women as symbols rather than individuals (Mikhail 2011), Nasrallah's work individualises each woman and enables her to control her destiny. From the beginning of the novel, women's value is emphasised: "the only thing that was never allowed at any time [in the houses of Hajj Mahmoud, Khaled's father, and his father's] was to insult a woman" (Nasrallah 2012, 38). One of the distinguished women characters in the novel is Rayhana.

Rayhana's contribution in demolishing the only Palestinian tyrant in the novel is as important as Khaled's as will be analysed later. She is the only woman in the narrative that defies the sole patriarchal power, Habbab. From this perspective, Nasrallah defies the Arab/Palestinian male dominated narrative and culture; he deconstructs the patriarchal binary thought which entails that "the male constitutes the norm, the positive, and the superior; the female is the aberration, the negative, the inferior" (Eagleton 1982, 204). Habbab is a ferocious, dishonest person who confiscates properties and people alike. His mere name inspires "dread both near and far" (Nasrallah 2012, 206). In fact, the presence of Habbab in Nasrallah's novel is the means by which he deconstructs the ideal past of Palestine prevalent in the narratives of many Palestinian camp residents who usually lament the old days saying: "We lived in Paradise" (Sayigh 2007, 1).

Rayhana begins defying Habbab by refusing to marry him after the latter deliberately kills her husband for the sole reason of marrying her. As a sexual relationship is in some cases a form of interior colonisation (Cesairé 1997, 81; Millett 1971, 25), Rayhana resists consensual sex with her enforced husband by challenging him to mount Adham, her late husband's horse. Nevertheless, Adham refuses to "get a saddle on his back" (Nasrallah 2012,112) by anyone after the death of his owner. Rayhana's attitude is challenging because none of Habbab's previous wives or other women, who were forced to marry him, ever 
defied him. That is why Rayhana's condition and words were a breach of his manhood; "an eerie tremor went through him like a fine blade" (Nasrallah 2012, 112). Defying Habbab enables Rayhana to possess the phallic power represented in the "blade" that cuts through Habbab's inside. Here it is an inversion of power relations, from a male dominated relationship to a female dominated one. Failing to mount Adham becomes the catalyst which brings Habbab's downfall. In representing Rayhana as such, Nasrallah defies the lack of representation of Palestinian women in the Palestinian/Arab metanarrative.

\section{Foregrounding the Palestinian Fellahin's Resistance}

As mentioned earlier, the epic novel is suitable in the context of representing the Palestinian chivalrous past that Nasrallah is concerned with. Khaled, the main character in Time of White Horses, is a typical epic hero. He symbolises honourable chivalrous Palestinian men who make any Palestinian proud. However, Khaled's qualities and actions that could be described as legendary in the beginning of the narrative, develop to be realistic throughout the course of the narrative. Khaled's legendary and sometimes mythological aspects in Nasrallah's narrative contradict the authentic portrayal of pre-Nakba Palestine that the author tries to present in his novel. It also attributes the Palestinian past to fantasy which renders Nasrallah's effort to re-write the Palestinian resistance history at risk of being merely the work of the Palestinians' wild imagination.

Nevertheless, representing a legendary character could be traced to Nasrallah's early years in the refugee camp. Nasrallah's parents were Palestinian refugees who probably arrived at Jordan in a devastating state and had to reside in Al-Wihdat Refugee Camp. Being the headquarters of the Palestinian guerrillas, Al-Wihdat camp was heavily bombarded by the Jordanian army in 1970 (Tuastad 2010, 27). Born in the camp, suppressed, and a refugee, could all be factors that drew Nasrallah to investigate the lost glorious Palestinian history. Further, the "sons of the camp," that refer to the fedayeen "embodied the archetypal Palestinian" (Achilli 2015) man who stands for courage and willingness to sacrifice himself for the nation; the reflection of such an image is found in Nasrallah's Khaled.

Presenting a heroic and legendary Palestinian fedayee like Khaled necessitates the use of the epic genre. Nasrallah writes a novel that is based on the Palestinian national history during Ottoman Palestine until pre-Nakba Palestine which sets it far away from the reader's temporality. Time as a concept is also quite important in the epic genre: it "is not just that the epic's events occur in an idealized past [but also] ... the timeframe of the epic is resolutely closed, and nothing more can be added" (Head 2011, 157); thus, in the novel, the defeat 
of the present can never change this closed glorious Palestinian past. It is significant and appropriate that the events of the novel take place in the past since the Palestinian present is saturated with occupation, expulsion and exile. The first chapter of the novel resembles the beginning of the Arabic epics. The arrival of the mare Hamama, acts as the delineator that traditionally marks the beginning of the stories in Arabic epics (Lyons 1995, 73). Hamama's arrival begins Khaled's journey in this Palestinian saga. Khaled is the embodiment of chivalry and honour who will accomplish heroic deeds throughout the course of the narrative.

As the central character, Khaled Al-Hajj Mahmoud is a typical epic hero. He combines both extraordinary characteristics and human ones; he represents the saviour's image present in his people's consciousness that would relieve them from a horrific nightmare (Khorshid 1994, 96). Khaled, who develops to be Hajj Khaled, symbolises the Palestinian leaders and fedayeen whose achievements in resisting the British coloniser during the Palestinian Revolt are glorified. Like the hero of the Arabic epic that acquires "an extraordinary sword and an exceptionally powerful steed at the start of his career" (Kruk 2014, 1), Khaled has the exceptional mare Hamama and is set on a mission to bring down tyranny and resist occupation. However, Khaled is not a mere fictional character; his historical roots could have been based on the Palestinian fedayee Abdel-Raheem Al-Hajj Mohammed (1892-1939) ${ }^{9}$ or Al-Qassam.

Khaled's heroism begins locally in the village and develops externally to fight for Palestine. His internal victory is manifested in his encounter with Habbab. Khaled, now a young man disguised as a Bedouin, defies Habbab, tactfully destroys his legacy and restores peace and security to his small community. Externally, Khaled defies the Ottoman and English colonial powers: the main incident that elevates Khaled to the level of legendary heroes is his victory over with the Turkish military police. Dissatisfied with the taxes paid by Hadiya's villagers, the Ottoman authority sends a delegate of a tax collector, a military assistant and soldiers to Hadiya that steal Hamama, cattle, sheep, horses and camels. Stealing a horse, as was established in the beginning of the narrative, is an act that breaches the village's moral codes; consequently, Khaled's mission entails returning the honour and right of his village. The Palestinian epic hero's plight reveals his tact, resilience, courage and prowess. Reaching the delegate while being off sight, Khaled threatens the group several times. He begins with: "[t]he mare, or your lives! Let her go and take everything you've stolen from us!" (Nasrallah 2012, 145), until he reaches "Let her go, as well as everything you've stolen from us!" (149) and restores his precious Hamama and all the 
stolen livestock of his people. With each threat Khaled courageously kills one member of the well-armed Ottoman delegation. As a result, his people elevate him to the level of folktale heroes: "it wasn't unusual for a child to ask his mother to tell him 'stories about Khaled' before he went to sleep, the way she might have told him stories about ... 'al-shatir Hasan', and 'Pretty Girl'" (Nasrallah 2012, 182).

However, Khaled develops from being a mere legendary figure to a realistic one; he has developed, through the course of the novel, from being a young man who solely overcomes his enemies in a mysterious, heroic, and hyperbolic way to a realistic Palestinian fedayee that -- among other Palestinians and volunteers -- resists the British occupation of Palestine during the Palestinian Revolt. Resisting occupation signifies the Palestinian national spirit that sprang in the end of the nineteenth century. The Palestinian identity was created as opposed to the British and, later, the Zionist occupations; it "solidified the Palestinian sense of belonging ... to a distinct national group with a language (the Palestinian Arab dialect) and a specific communal sense ... of its own" (Said 1992, 12). It is this Palestinian national identity that Nasrallah effectively foregrounds in his novel.

Blending the boundaries between history and fiction, Nasrallah embodies the historical figures of Al-Qassam and Abdel-Raheem Al-Hajj Mohammed in his fictional character of Hajj Khaled. Defying the Palestinian/Arab metanarrative and reincarnating the legacy of Al-Qassam, Nasrallah presents the military prowess of Hajj Khaled. Al-Qassam, for the Palestinians, represents a "hero of the liberation struggle and a model of patriotic sacrifice" (Swedenburg 1995, 1). He left Haifa with his comrades and resided in the mountain to declare military resistance against the British coloniser in 1935 and initiated the first Palestinian guerrilla force to resist the British and Zionist colonisers (Ibrahim 2005, 154; Kimmerling and Migdal 2003, 94). Likewise, Hajj Khaled took to the mountains alongside many volunteers to resist the British Occupation: "[ $t]$ here wasn't a mountain left in all of Palestine, but that Hajj Khaled had made it his home" (Nasrallah 2012, 379). He ferociously fought the British coloniser but was doomed, like many Palestinian fedayeen to die at the hands of the enemy. The death of Hajj Khaled is probably inspired by the death of Abdel-Raheem Al-Hajj Mohammed: both were trapped in a village, and their whereabouts were leaked to the British by Palestinian infiltrators. Both were surrounded by three lines of forces, refused to escape and chose to fight till they were killed by the British forces (Nasrallah 2012, 459; Arrar 2009; Abu Azza 2013). In the chapter entitled "The Will," the British finally succeed in killing Hajj Khaled; however, his last will to the Palestinians/fighters of his village and his family is: "[b]eware of 
losing forever" (Nasrallah 2012, 458) which paradoxically foreshadows the Nakba and an eventual victory that is yet to come. Though Hajj Khaled was caught in an ambush, his killing scene culminates his heroic representation that has been built up since the beginning of the narrative. Hajj Khaled and his fellow fedayeen Nur, and Iliya Radhi were "confronted unexpectedly by half the soldiers, who stood with their rifles expertly aimed. [Trying to charge ahead, they] came up against a wall of soldiers with their bayonets at the ready" (Nasrallah 2012, 460). However, Hajj Khalid manages to come out of this encounter with a bullet through his shoulder only to be faced with a third barrier which consists of "three armored cars and a number of jeeps in the middle of it" (Nasrallah 2012, 460). Though certain of his death, Hajj Khaled is determined to resist the colonisers; "he fired several shots right at the soldiers ... He saw one of them fall before a sudden fog descended and filled his eyes" (Nasrallah 2012, 461). Both Hajj Khaled and Al-Hajj Mohammed were able to trespass three military barriers to be engaged with the third one, they kept fighting until the last moment when they were shot (Abu Azza 2013).

The fictional Hajj Khaled and real Al-Hajj Mohammed's burials were attended by Major General Bernard Montgomery: the commander of the British forces in northern Palestine. Hajj Khaled's death is a graceful one that won him the respect of Peterson, who was in fierce trials to catch him. Peterson admits that Hajj Khaled was a courageous and honourable man and refuses to be congratulated for conquering him. Hajj Khaled's burial scene, like Al-Hajj Mohammed's, is one of war heroes. After laying his body in the grave, "a number of soldiers formed a queue and fired in the air in a gesture of respect, while Peterson and Montgomery and the senior officers saluted the deceased" (Nasrallah 2012, 462). In this part, Nasrallah successfully uses one of the features of historiographic metafiction, which is blending the real with the fictional in an attempt to resist the rigid Western and Zionist grand narrative that marginalises the Palestinians. This is not to suggest that Nasrallah's narrative is a mere reflection of a historical event, since the aesthetics of the narration offer a richer insight into the incident that history books and archives can never catch. The dynamics of the epic character and his relation to other characters, the development Khaled undergoes from the epic figure to the fedayee paradoxically adds to the 'authenticity' of the narrative fiction as they reinforce the human aspect of Khaled's depiction. 


\section{Textual Aesthetics}

One of the main features of historiographic metafiction used in Nasrallah's novel is transtextuality. The novelist uses transtextuality to further deconstruct the Zionist slogan. He uses transtextuality through the use of paratextuality and intertextuality. The first element of paratextuality is peritext manifested in Nasrallah's use of a preface. Nasrallah uses the preface to evoke truthfulness; he writes "[t]he story of the monastery in the village of Hadiya is true from beginning to end. It is the story of my village" (Nasrallah 2012, x). His sincerity is manifested by declaring that his novel is based on oral testimonies of uprooted and exiled Palestinians (Nasrallah 2012, ix), but at the same time, he uses what Genette calls "the contract of fiction" $(1997,217)$ in declaring that "names of all individuals and families that appear in this work are fictitious, and any resemblance between them and those of real people, living or dead, is purely coincidental" (Nasrallah 2012, x). Such authorial intention reflects the historiographic metafictional element of blending fiction with reality, which clearly runs throughout Nasrallah's narrative.

Another element of peritext is notes. Nasrallah inserts footnotes in the middle of his narrative in which he adds historical events related to the narrative and comments or adds new information about the characters or the Palestinian traditions. He uses footnotes to "verify, validate, authenticate and historicize fictional narrative" (Harb and Matar 2013, 93). Peritext has a discursive function; footnotes function as "self-reflexive signals to assure the reader as to the historical credibility of the particular witness or authority cited, while at the same time they also disrupt our reading -- that is, our creating -- of a coherent, totalizing fictive narrative" (Hutcheon, 2005, 81). Nasrallah's footnotes provide the reader with historical information outside the text; for example, he states the date of appointing the first Greek patriarch in the church of Jerusalem and ends with the colonial fact that the Palestinian elements were excluded "from the patriarchate's administration and from higher ecclesiastical positions" (Nasrallah 2012, 34). Crucial to the narratives of resistance, as Harlow believes, "is the demand they make on the reader in their historical referencing and the burden of historical knowledge such referencing enjoys" (1987, 80). Thus, Nasrallah authenticates and verifies his narrative.

Intertextuality is manifested in the voices of witnesses, including women voices in Nasrallah's fiction. Nasrallah uses italicised letters to differentiate between what seems to be eye witness accounts of the events and the novel's omniscient narrator. These eye-witness accounts are used as historical documents which are used "for both its metafictive and historical suggestibility" (Hutcheon 2017, 8). However, again, he does not make a clear distinction 
between fact and fiction; he does not clarify whether these testimonies are eyewitness accounts of fictional characters or real ones. In the chapter entitled "Battlement of Fire", Nasrallah uses intertextuality and paratextuality by means of testimony and footnotes. The whole chapter is the testimony of a Palestinian veteran who witnessed one of the battles between the Palestinian fedayeen and the British-Zionist joint forces. The testimony, written in italics, is supposedly a historical account of the battle scene; however, the witness brings details related to the fictional Hajj Khaled, which leaves the narrative lingering between fiction and history. The chapter begins with a real historical event: the assassination of General Andrews. A footnote was written explaining the assassination of General Lewis Yelland Andrews (1896-1937) intermingled with an omniscient narrator who narrates the testimony of the Palestinian fedayee who did the assassination. The story bears historical resemblance to the actual event of assassinating General Andrews in 1937 (Ibrahim 2005, 165).

\section{Conclusion}

Being part of a greater Palestinian literary project, Time of White Horses explores the life of nineteenth century Palestinian fellahin who enjoyed culture and traditions, and were attached to their land and ferociously fought for it. Nasrallah's work "calls attention to itself ... as a political and politicized activity" (Harlow 1987, 28-9). By blending fact and fiction, Nasrallah elaborates upon the glorious past of the Palestinians who resisted different colonial powers, especially the British one during the Palestinian Great Revolt. Centralising the Revolt is significant as it simultaneously deconstructs the Zionist grand narrative and defies the Palestinian/Arab metanarrative. Through exploring the Palestinian culture, experience, resilience, and certainly resistance, Nasrallah deconstructs the Zionist grand narrative generally and the famous Zionist slogan "a land without a people for a people without land" particularly. Nasrallah is well aware of the misrepresentation of the Nakba in the Palestinian/Arab metanarrative. Accordingly, in his novel, he sought to defy the male dominated metanarrative by presenting strong willed women, like Rayhana. Reinforcing Palestinian historical leaders like Al-Qassam and reincarnating other Palestinian fedayeen like Al-Hajj Mohammed; he explores areas of the Palestinian history that are deliberately hidden in both mainstream narratives. This acclaimed Palestinian writer even used literary aesthetics to further resist and defy the Zionist grand narrative and the Palestinian/Arab metanarrative respectively. By writing Time of White Horses Nasrallah seems to answer 'Issa's questions "why is it that Palestinians are still, by and large, represented by others? ... what happened to 
all Palestinian intellectuals and revolutionaries?" ('Issa 2005, 180). Nasrallah succeeds indeed in representing an authentic Palestinian counter-hegemonic Nakba narrative from the ground up.

\section{Endnotes}

${ }^{1}$ Zionist Yishuv: is "a predominantly European settler community immigrated into Palestine in the period between 1882-1948" (Masalha 2005, 1).

${ }^{2}$ The French literary theorist, philosopher and sociologist, Jean-François Lyotard explains that metanarratives/grand narratives are presented by a hegemonizing system as master narratives and are also perceived as the absolute truth (60). Thus, grand narrative and metanarrative are used interchangeably throughout my paper.

${ }^{3}$ The famous Zionist slogan is formulated by the British author Israel Zangwill (Said 1992, 9). The Palestinian Professor of History Bishara Doumani sees that this slogan entails "the absence of 'civilized' people, in the same sense that the Americas and Africa were portrayed as virgin territories ready for waves of pioneers" $(2007,15)$. Said explains that this slogan means "to cancel and transcend an actual reality - a group of resident Arabs - by means of a future wish - that the land be empty for development by a more deserving power" $(1992,9)$.

${ }^{4}$ Nasrallah recently won the International Prize for Arabic Fiction in 2018 for his novel The Second War of the Dog published in 2016 (International Prize for Arabic Fiction 2018).

${ }^{5}$ The Palestinian Comedy covers, throughout seven novels, 250 years of modern Palestinian history. The project includes: Birds of Caution (1996), Eraser Child (2000), Olive Trees of the Streets (2002), Safe Weddings (2004), Under the Midmorning Sun (2004), Time of White Horses (2007), and Lantern of the King of Galilee (2012).

${ }^{6}$ For more about the Palestinians' image in the Zionist grand narrative, refer to Edward Said's The Question of Palestine (1992, 3), Benny Morris's Righteous Victims: A History of the Zionist-Arab Conflict 1881-2001 (2001, 43), and Susanne Hillman's "Of Snake -Catchers and Swamp-Drainers: Palestine and the Palestinians in Central European Zionist Discourse, 1891-1914" (2009, 7).

${ }^{7}$ See Leon Uris's Exodus (1958). For more about the religious motif in the Zionist grand narrative, refer to Mohamed Doudi and Zeina Barakat's "Israelis and Palestinians: Contested Narratives."

${ }^{8}$ See, for example, Mahmoud Darwish's (1941-2008) "Lover from Palestine"/ "Ashiq min Filastin" and "He Came Back in a Shroud"/“"Wa-Ada fi Kafan."

${ }^{9}$ For Abdel-Raheem Al-Hajj Mohammad's biography refer to Mohammad Aqel's article "Abdel-Raheem Al-Hajj Mohammad Al-Qaed Al-A'ala LelThawra Fy Filasteenn" ("Abdel-Raheem Al-Hajj Mohammad: Abdel-Raheem Al-Hajj Mohammed: The Supreme Leader of the Revolt in Palestine"). 


\section{Works Cited}

Abu Azza, Mohammed. 2013. Ashaheed AbdelRaheem Al-Hajj Mohammed (Abu Kamal) (The Martyr AbdelRaheem Al-Hajj Mohammed (Abu Kamal)). Palestine Culture Foundation. $<$ http://www.safsaf.org/sejil-alsharaf/elhajjmohamad-moha-abouizza.htm>.

Achilli, Luigi. 2015. "Al-Wihdat Refugee Camp: Between Inclusion and Exclusion." Jadaliyya, The Arab Studies Institute, February 12, 2015. $<$ https://www.jadaliyya.com/pages/index/20831/al-wihdat-refugeecamp_between-inclusion-and-exclu>.

Al Jazeera English. 2013. "Head to Head - Israeli Settlers: Patriots or Invaders?" YouTube, July 6, 2013.

$<\mathrm{https}: / / \mathrm{www}$.youtube.com/watch? $\mathrm{v}=\mathrm{m} 6 \mathrm{lwgCs} 2 \mathrm{PNM}>$.

Al-Moubaid, Saleem Arafat. 1990. Malameh Al-Shakhsya Al-Falasteinya men Amthaleha Al-Sha'abya (Features of the Palestinian Character as Indicated in the Palestinian Proverbs). Cairo: General Egyptian Book Organization.

Aqel, Mohammad. 2014. "Abdel-Raheem Al-Hajj Mohammad Al-Qaed AlA'ala LelThawra Fy Filasteenn" ("Abdel-Raheem Al-Hajj Mohammad: Abdel-Raheem Al-Hajj Mohammed: The Supreme Leader of the Revolt in Palestine"). Jerusalem Journals, no. 18, (Autumn-Winter): 80-88.

Arrar, Abdel Aziz Amin. 2009. Thinnaba: Al-Kaed Al-A'am Al-Mojahed AbdelRaheem Al-Hajj Mohammed-Al-Shakhsya Al-Markazya fy Thawret 1936-1939 (Thinnaba: The Commander Mojahed AbdelRaheem Al-Hajj Mohammed- The Central Fighter in The Palestinian Revolt 1936-1939). 8 Aug. 2009.

$<$ http://www.palestineremembered.com/GeoPoints/Thinnaba_941/Article_1 4650.html>.

Aumann, Moshe. 1974. Land Ownership in Palestine, 1880-1948. Israel Academic Committee on the Middle East.

Bakhtin, Mikhail Mikhailovich. 1981. The Dialogic Imagination, edited by Michael Holquist. Translated by Caryl Emerson and Michael Holquist. Austin: U of Texas P.

Büssow, Johann. 2011. Hamidian Palestine: Politics and Society in the District of Jerusalem 1872-1908. Leiden and Boston, MA: Brill.

Cesairé, Aimé. 1997. "Discourse on Colonialism." Postcolonial Criticism, edited by Bart Moore-Gilbert, Gareth Stanton and Willy Maley, 73-90. London: Longman.

Darwish, Mahmoud. 2005. "Ashiq Min Filastin (Lover from Palestine)." Adab 25 (Aug. 2019): n. pag. 
$<$ http://www.adab.com/modules.php?name=Sh3er\&doWhat=shqas\&qid=64 $762>$.

---. 2005 "Wa-Ada Fi Kafan (He Came Back in a Shroud)." Adab 25 (Aug. 2019): n. pag.

$<$ http://www.adab.com/modules.php?name=Sh3er\&doWhat=shqas\&qid=64 $743 \& \mathrm{r}=\& \mathrm{rc}=14>$.

Daoudi, Mohammed S. Dajani and 7eina M. Barakat. 2013. "Israelis and Palestinians: Contested Narratives." Israeli Studies 18, no. 2: 53-69.

Docker, John. 2004. "Raphael Lemkin's History of Genocide and Colonialism." United States Holocaust Memorial Museum, Feb. 26, 2004.<https://www.ushmm.org/confront-genocide/speakers-and-events/allspeakers-and-events/raphael-lemkins-history-of-genocide-and-colonialism>.

Doumani, Bishara B. 2007. "Rediscovering Ottoman Palestine: Writing Palestinians into History." The Israel/Palestine Question: A Reader, edited by Ilan Pappé, 11-39. New York: Routledge.

Eagleton, Terry. 1982. The Rape of Clarissa: Writing, Sexuality, and Class Struggle in Samuel Richardson. Oxford: Blackwell.

Essaid, Aida. 2014. Zionism and Land Tenure in Mandate Palestine. New York: Routledge.

Fanon, Franz. 1970. The Wretched of the Earth. New York: Penguin Books.

Faulkner, William. 1985. Novels 1930-1935, edited by Joseph Blonter and Noel Polk. New York: The Library of America.

Foucault, Michel. 1980. Power/Knowledge: Selected Interviews and Other Writings 1972-1977, edited by Colin Gordon. Translated by Colin Gordon, et al. New York: Pantheon Books.

Genette, Gérard. 1997. Palimpsests: Literature in the Second Degree. Translated by Channa Newman and Claude Doubinsky. Lincoln: U of Nebraska P.

--- 1997. Paratexts: Thresholds of Interpretation. Translated by Jane E. Lewin. New York: Cambridge UP.

Gramsci, Antonio. 2007. Prison Notebooks, edited by Joseph A. Buttigieg. Translated by Joseph A. Buttigieg, vol. III. New York: Columbia UP.

Harb, Zahera and Dina Matar. 2013. Narrating Conflict in the Middle East: Discourse, Image and Communications Practices in Lebanon and Palestine. London and New York: I. B. Tauris.

Harlow, Barbara. 1987. Resistance Literature. New York: Methuen.

Head, Gretchen. 2011. "The Performative in Ilyās Khūrī's Bāb al-Shams." Journal of Arabic Literature 42: 148-82. 
Hillman, Susanne. 2009. "Of Snake-Catchers and Swamp-Drainers: Palestine and the Palestinians in Central European Zionist Discourse, 1891-1914." Holy Land Studies, no.1: 1-29.

Hilu, Alon. 2008. The House of Rajani. London: Harvill Secker.

Hutcheon, Linda. 2000. A Poetics of Postmodernism: History, Theory, Fiction. New York: Routledge.

--- 2005. The Politics of Postmodernism. New York: Routledge.

---. 2017. "Postmodern Paratextuality and History", TEXTE, 2017: 301-12. $<$ http://www.tspace.library.utoronto.ca/bitstream/1807/9477/1/TSpace0031. pdf $>$.

Ibrahim, Rashid Al-Hajj. 2005. Addefa A'n Haifa wa Kadiat Filastin: Mothakkerat Rashid Al-Hajj Ibrahim (Defending Haifa and the Problem of Palestine: The Memoirs of Rashid al-Hajj Ibrahim), 1891-1953. Beirut: Institute For Palestine Studies.

"Ibrahim Nasrallah." 2015. International Prize for Arabic Fiction, 2015. $<$ https://www.arabicfiction.org/en/Ibrahim-Nasrallah>.

International Prize for Arabic Fiction. 2018. "Ibrahim Nasrallah Wins 2018 International Prize for Arabic Fiction." April 24, 2018. $<$ https://www.arabicfiction.org/en/winnerannouncement2018>.

'Issa, Mahmoud. 2005. "The Nakba, Oral History and the Palestinian Peasantry: The Case of Lubya." Catastrophe Remembered: Palestine, Israel and the Internal Refugees, edited by Nur Masalha, 178-196. London: Zed Books.

Kark, Ruth. 2017. "Consequences of the Ottoman Land Law: Agrarian and Privatization Processes in Palestine, 1858-1918." In Societies, Social Inequalities and Marginalization, 101-19. Cham: Springer International Publishing.

Khorshid, Farouk. 1994. Asseira Asha'abya (Folk Tales). London: Longman.

Kimmerling, Baruch and Joel S. Migdal. 2003. The Palestinian People: A History. Cambridge: Harvard UP.

Kruk, Remke. 2014. The Warrior Women of Islam: Female Empowerment in Arabic Popular Literature. London and New York: I. B. Tauris.

Lyons, M. C. 1995. The Arabian Epic: Heroic and Oral Story-Telling. vol. 1. New York: Cambridge UP.

Lyotard, Jean-François. 1993. The Postmodern Condition: A Report on Knowledge. Translated by Geoff Bennington and Brian Massumi. Minneapolis: U of Minnesota P.

Mahafzah, Mohammad Abd Al-Kareem and Zuhair Ghanaim Abd Al-Lateef. 2009. "Fees and Taxes from Agricultural Lands in Palestine during 
(921/1246AH-1516/1831AD)." Jordan Journal for History and Archaeology: 75-100.

Masalha, Nur. 1993. Expulsion of the Palestinians: The Concept of Transfer in Zionist Political Thoughts, 1882-1948. Washington DC: The Institute of Palestine Studies.

---. 2005. Introduction to Catastrophe Remembered: Palestine, Israel and the Internal Refugees: Fssays in Memory of Edward W. Said, edited by Nur Masalha, 1-20. London: Zed Books.

---. 2012. The Palestine Nakba: Decolonising History, Narrating the Subaltern, Reclaiming Memory. London: Zed Books.

Mikhail, Mona. 2011. "The Role of Women in Arabic Literature." Cornwell University.

$<\mathrm{http}$ :/Www.collectiondevelopment.library.cornell.edu/mideast/litera1.htm> Millett, Kate. 1971. Sexual Politics. New York: Avon Books.

Mir, Salam. 2013. "Palestinian Literature: Occupation and Exile." Arab Studies Quarterly 35, no. 2: 110-29.

Morris, Benny. 2001. Righteous Victims: A History of the Zionist-Arab Conflict 1881-2001. New York: Vintage Books.

---. 2004. The Birth of the Palestinian Refugee Problem Revisited. New York: Cambridge UP.

Nasrallah, Ibrahim. 2012. "On Writing the Palestinian Historical Novel." Sheffield Palestine Solidarity Campaign, November 16, 2012. $<\mathrm{https}$ ://www.sheffieldpsc.org.uk/content/events/meet-ibrahim-nasrallah>.

---. 2012. Time of White Horses. Translated by Nancy Roberts. Cairo: The American U in Cairo P.

Oppenheimer, Yochai. 2012. "How Bound the Arab is to His Land': The House of Rajani and the Limits of Zionist Discourse." Prooftexts: A Journal of Jewish Literary History 32, no. 3: 381-408.

Ramras-Rauch, Gila. 1989. "Moshe Smilansky: Utopia and Reality." Shofar 7, no. 3 (Spring): 3-12.

Robson, Laura. 2011. Colonialism and Christianity in Mandate Palestine. Austin: U of Texas P.

Ruedy, John. 1971. "The Dynamics of Land Alienation." The Transformation of Palestine, edited by Ibrahim Abu-Lughod, 119-138. Evanston, Illinois: Northwestern UP.

Said, Edward. 1993. Culture and Imperialism. New York: Vintage Books, 1994.

---. 1979. The Question of Palestine. New York: Vintage Books, 1992.

---. 1978. Orientalism. New York: Vintage Books, 1994. 
Sayigh, Rosemary. 2007. The Palestinians from Peasants to Revolutionaries. London: Zed Books.

Slyomovics, Susan. 1998. The Object of Memory: Arab and Jew Narrate the Palestinian Village. Philadelphia: U of Pennsylvania P.

Swedenburg, Ted. 1995. Memories of Revolt: The 1936-1939 Rebellion and the Palestinian National Past. Minnesota: U of Minnesota P.

Tuastad, Dag. 2010. "Al-Wihdat: The Pride of the Palestinians in Jordan." Middle East Institute Viewpoints: Sports and the Middle East, (May): 24-28. Uris, Leon. 1958. Exodus. New York: Doubleday \& Company, Inc. 